\title{
Water uncertainty, ritual predictability and agricultural canals at Chaco Canyon, New Mexico
}

Vernon L. Scarborough ${ }^{1, *}$, Samantha G. Fladd ${ }^{1,2}$, Nicholas P. Dunning ${ }^{3}$, Stephen $\operatorname{Plog}^{4}$, Lewis A. Owen ${ }^{5}$, Christopher Carr ${ }^{3}$ Kenneth B. Tankersley, ${ }^{1,5}$, Jon-Paul McCool ${ }^{3,6}$, Adam S. Watson ${ }^{7}$, Elizabeth A. Haussner ${ }^{8}$, Brooke Crowley ${ }^{1,5}$, Katelyn J. Bishop ${ }^{9}$ David L. Lentz ${ }^{10} \&$ R. Gwinn Vivian ${ }^{11}$

The Pueblo population of Chaco Canyon during the Bonito Phase (AD 800-1130) employed agricultural strategies and water-management systems to enhance food cultivation in this unpredictable environment. Scepticism concerning the timing and effectiveness of this system, however, remains common. Using optically stimulated luminescence dating of sediments and LiDAR imaging, the authors located Bonito Phase canal features at the far west end of the canyon. Additional ED-XRF and strontium isotope (87Sr/86Sr) analyses confirm the diversion of waters from multiple sources during Chaco's occupation. The extent of this water-management system raises new questions about social organisation and the role of ritual in facilitating responses to environmental unpredictability.

Keywords: Chaco Canyon, Bonito Phase, water management, OSL dating, LiDAR, ED$\mathrm{XRF},{ }^{87} \mathrm{Sr} /{ }^{86} \mathrm{Sr}$

1 Department of Anthropology, University of Cincinnati, 481 Braunstein Hall, Cincinnati, OH 45221, USA

2 School of Anthropology, University of Arizona, 1009 E. South Campus Drive, Tucson, AZ 85721, USA

3 Department of Geography and GIS, University of Cincinnati, 401 Braunstein Hall, Cincinnati, OH 45221, USA

4 Department of Anthropology, University of Virginia, 1702 University Avenue, 100 Brooks Hall, Charlottesville, VA 22903, USA

5 Department of Geology, University of Cincinnati, 500 Geology Physics Building, Cincinnati, OH 45221, USA

6 Department of Geography \& Meteorology, Valparaiso University, Kallay-Christopher Hall, 1809 Chapel Drive, Valparaiso, IN 46383, USA

7 Division of Anthropology, American Museum of Natural History, Central Park West at $79^{\text {th }}$ Street, New York, NY 10024, USA

8 Department of Earth and Planetary Sciences, American Museum of Natural History, Central Park West at $79^{\text {th }}$ Street, New York, NY 10024, USA

9 Department of Anthropology, University of California, Los Angeles, 375 Portola Plaza, 341 Haines Hall, Los Angeles, CA 90095, USA

10 Department of Biological Sciences, University of Cincinnati, 614 Rieveschl Hall, Cincinnati, OH 45221, USA

11 Department of Archaeology, Arizona State Museum, 1013 E. University Boulevard, Tucson, AZ 85721, USA

Author for correspondence (Email: scarbovl@ucmail.uc.edu)

(C) Antiquity Publications Ltd, 2018

ANTIQUITY 92364 (2018): 870-889

https://doi.org/10.15184/aqy.2018.114 


\section{Introduction}

In the water-limited U.S. Southwest, the dynamic interplay between the arid setting and sedentary Ancestral Pueblo farmers resulted in an uncertainty that pervaded society, with unpredictable rainfall often providing insufficient moisture for maize agriculture. In particular, some researchers identify Chaco Canyon, located in the San Juan Basin of New Mexico, as an "unlikely setting" for substantial occupation (Lekson 2006: 9). Despite concerns about the environmental feasibility for occupation and debates over population size, the Canyon served as a social and political centre of Pueblo society from AD 800-1130 (Figure 1). Large multi-storeyed pueblos-known as great houses-were concentrated within a $17 \mathrm{~km}$-long portion of the Chaco Wash, now preserved as the Chaco Culture National Historical Park (Lekson 2006; Heitman \& Plog 2015). Additionally, hundreds of small sites were constructed and occupied throughout the canyon, suggesting a sizable local population (McKenna \& Truell 1986; Sebastian 1992). The persistence of Chaco society for over 300 years indicates a remarkably sustainable system, but how this sustainability was achieved within an unpredictable environmental setting remains uncertain.

Debates over whether food was grown locally or supplied from distant settlements dominate the literature (e.g. Cordell et al. 2008; Benson 2016; Tankersley et al. 2016;

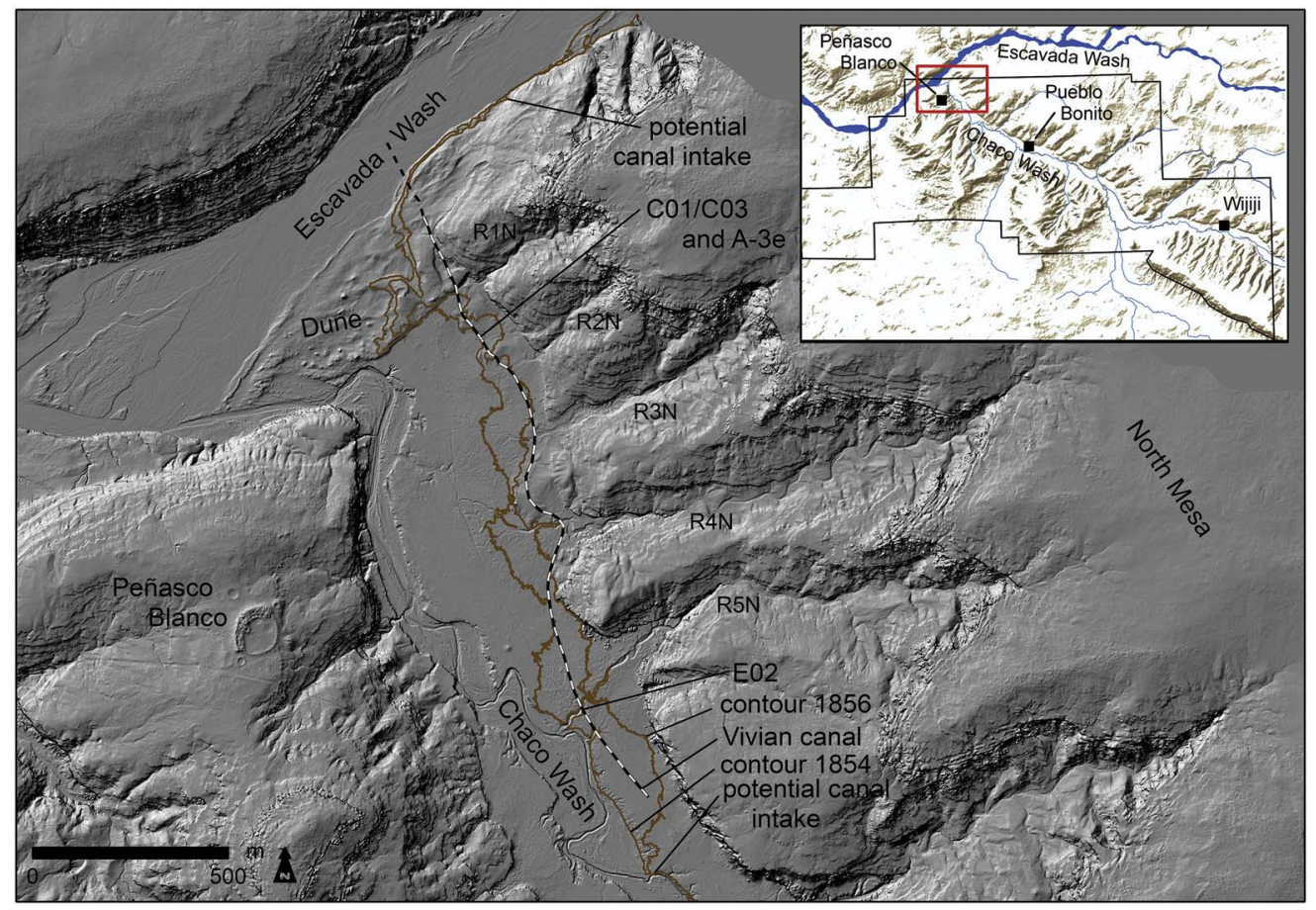

Figure 1. The dune end of Chaco Canyon where the Chaco Wash joins the Escavada Wash. The 'Vivian canal' was digitised from the Gordon Vivian map c. 1964 (CHCU-55430 1971 and online supplementary material (OSM) 7). The National Park boundary (in black) and the outline of this map (in red) are shown on the inset. Figure created by the authors.

(C) Antiquity Publications Ltd, 2018 
McCool et al. 2018). Arguments for the importation of maize, the staple crop, centre on two limiting factors: soil quality and water scarcity. Here, we examine the issue of water availability. Given the scarcity and unreliability of rainfall, technological advancements in water management were necessary for successful local agricultural production (Scarborough 2003). While the presence of complex canal systems has long been noted (e.g. Vivian 1990), the difficulty in dating these constructions has led to doubts over their existence and utility (e.g. Benson 2016; Wills 2017). Our recent fieldwork on one canal network definitively dates it to Chaco's Bonito Phase occupation (AD 800-1130), using optically stimulated luminescence (OSL) dating supplemented with AMS radiocarbon dates (online supplementary material (OSM) 1). We address the implications of this canal system (as well as others studied by R.G. Vivian) for the complexity of Chaco Canyon occupation, as water-flow coordination required flexible and quick responses from the local population. Pueblo social and political organisation, both past and present, is heavily integrated with ritual practices that help structure responses to the uncertain environment, including organising the labour necessary to maintain water-management infrastructure.

\section{Environmental unpredictability}

As the regional rainfall regime and the accessibility of water in the Chaco Wash can change rapidly, current conditions make for poor predictors of the past (Figure 2). Today, the Wash is deeply incised into valley-fill sediments, making flood-recessional farming or water-diversion irrigation nearly impossible. This, however, represents but one extreme in the oscillations between arroyo incision (or downcutting) and alluvial aggradation (or infilling) since the Middle Holocene (Bryan 1954; Hall 1977, 2010; Love 1980). Observations in the 1800 s indicate that the Wash was not entrenched at that time. The current degree of incision therefore has occurred within the last 150 years:

The [sic] cañon is here about 500 yards wide, and is perfectly level from one side to the other [...] Lieutenant Simpson passed through the cañon in August, and mentions that at this place there was a width of 8 feet, and a depth of 11/2 feet of running water in the arroyo (Jackson 1878: 437; see also Simpson 1850).

Recent research also demonstrates the dynamism of north-western New Mexico arroyo watersheds. Friedman et al.'s (2014: 626) analysis of living tree rings in relation to deposited sediment along arroyo drainage margins shows that measurable depositional changes could occur "at the scale of minutes to hours" (Friedman et al. 2014: 627).

Generally, the San Juan Basin has limited annual precipitation of about $200 \mathrm{~mm}$, with yearly fluctuations common and spatial distribution varying greatly. Precipitation in the ninth and tenth centuries $\mathrm{AD}$ experienced decadal fluctuations that became more consistent over time. Nevertheless, greater precipitation during the Bonito Phase may have increased options and opportunities for local agriculture. Except for 15 years, the period from AD 990-1115 received higher than average precipitation; this was followed by a significant drought, often assumed to be associated with canyon depopulation around AD 1130 (Sebastian 1992; Dean \& Funkhouser 2002; Vivian et al. 2006).

(C) Antiquity Publications Ltd, 2018 


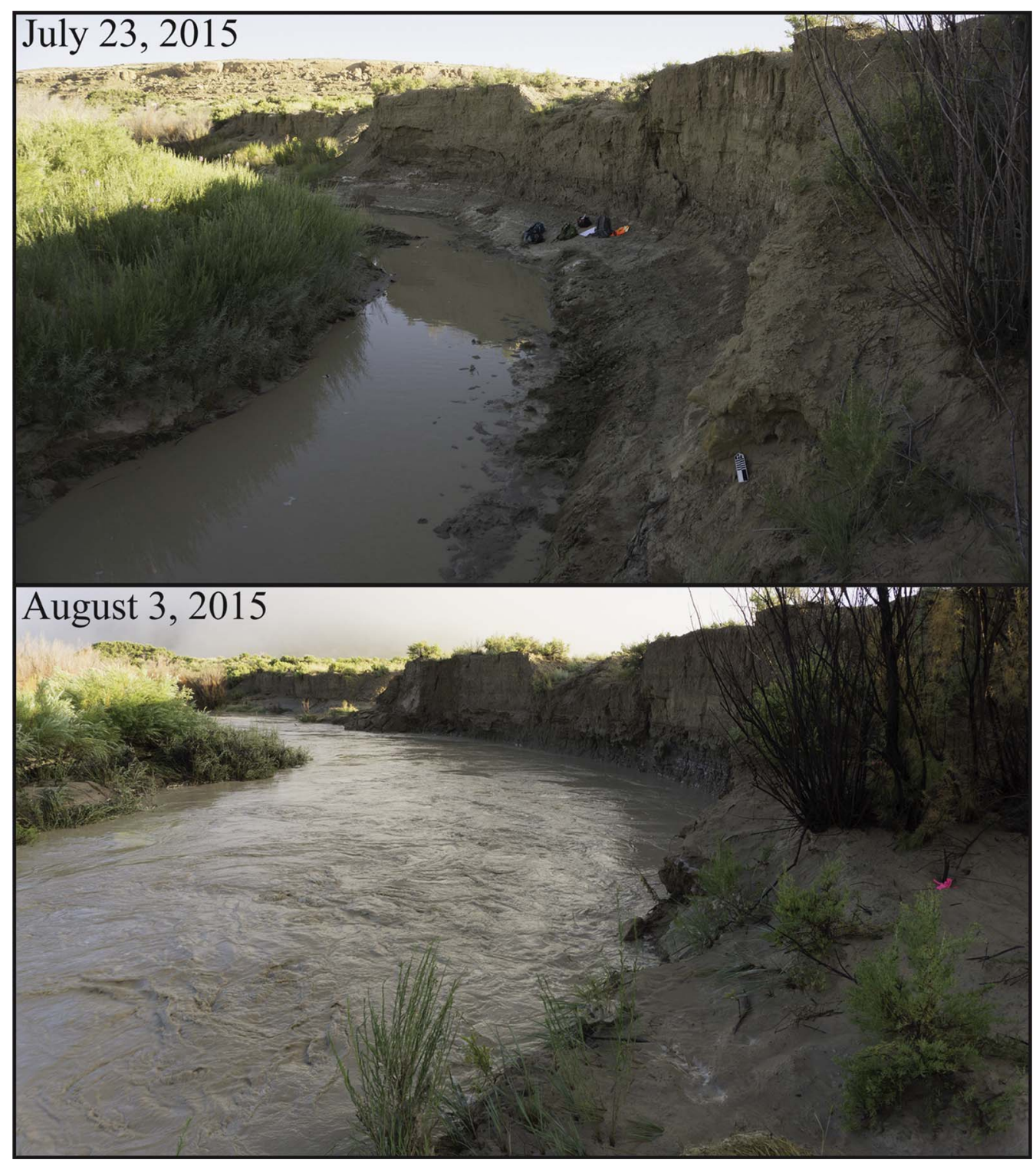

Figure 2. Two views of the 'horseshoe-bend' of the Chaco Wash showing about a $1.5 \mathrm{~m}$ water rise. Although the photographs were taken 11 days apart, the water rise occurred overnight. Photographs and figure created by the authors.

\section{Agricultural strategies}

Potential agricultural productivity within Chaco Canyon remains a debated topic (e.g. Vivian 1974, 1990; Sebastian 1992; Dorshow 2012; Benson 2016; Wills 2017). Questions about agricultural feasibility are linked, in part, with the salinity of the floodplain soils. A thorough review of arguments concerning salinity can be found in other papers

(C) Antiquity Publications Ltd, 2018 
(e.g. Wills \& Dorshow 2012; Benson 2016), but our research contends that modern salinity levels are low enough to permit farming and, given their susceptibility to spatial and temporal fluctuations, ultimately provide a poor measure of past agricultural potential (Tankersley et al. 2016; McCool et al. 2018). The recent revival of interest in Chaco agriculture, however, has highlighted the utilisation of a variety of past water-management systems that either have been documented archaeologically or were practised historically by Navajo farmers. These include floodplain, slope wash and ak chin (floodwater) farming (Vivian \& Watson 2015: 35-54). Archaeological features include terraces, check dams and canals (Vivian 1990; Wills \& Dorshow 2012; Vivian \& Watson 2015: 36-42).

On the floodplain, Vivian's $(1974,1990)$ excavations revealed multiple elaborate canal systems, largely concentrated on the north side of the canyon. These systems involved diversion gates of masonry, canals and fields - including a gridded field system first identified by Gordon Vivian, and located near the Chetro Ketl great house (Vivian \& Mathews 1965: 12). Sturm (2016) has found multiple overlaid field configurations in the area using groundpenetrating radar, while Wills et al. (2016) have identified a large channel that diverted floodwaters away from Pueblo Bonito, the central great house. Despite documentation of canal systems, the timing and effectiveness of these constructions for agriculture is often questioned—due in part to the lack of direct dating (e.g. Benson 2016; Wills 2017). We used a multi-faceted approach to address these concerns and to advance our understanding of the varied agricultural systems that supported the local population during the Bonito Phase.

\section{Recent excavations}

Our work in Chaco Canyon has involved sediment coring, arroyo sidewall sedimentary profiling, and excavation at both ends of the National Park's south-east and north-west boundaries (Watson et al. 2014; Scarborough et al. 2016) (Figure 1). We focused particularly on a zone at the confluence of the Chaco and Escavada Washes-often referred to as the 'dune dam' area. Peñasco Blanco, a great house on the mesa to the south, occupies an elevated and commanding vantage point. The greater dune dam area encompasses approximately $10 \mathrm{~km}^{2}$ (from the dune to rincon 5) of alluvium deposited from early meanders of the Chaco Wash, runoff from the North Mesa, and aeolian sands associated with dune development. Force et al. (2002) posited that the large linear sand dune functioned as a dam for the Chaco Wash during the Bonito Phase, although this hypothesis is controversial (Hall 2010; Love et al. 2011). Our data suggest the periodic deposition of clay-rich sediment-indicative of pond formation - behind the south-western end of the dune and in proximity to the present course of the Chaco Wash. This was followed by soil formation (vertisol), possibly stimulated by local base-level stability. An exposed profile from one cut-bank of the heavily incised lower 'horseshoe bend' within the Chaco Wash (Op. A08) and another from a test excavation $100 \mathrm{~m}$ north-east of the horseshoe-bend (Op. C02) indicate post-AD 400 clay deposition associated with widespread vertisol development (Figure 3) (Haussner 2016) (OSM 2).

\section{Canal profiles}

In the 1960s, Gordon Vivian carried out work in this area to investigate the local watermanagement system. Continuing this research during the 1970s, Vivian (1990) excavated (C) Antiquity Publications Ltd, 2018 


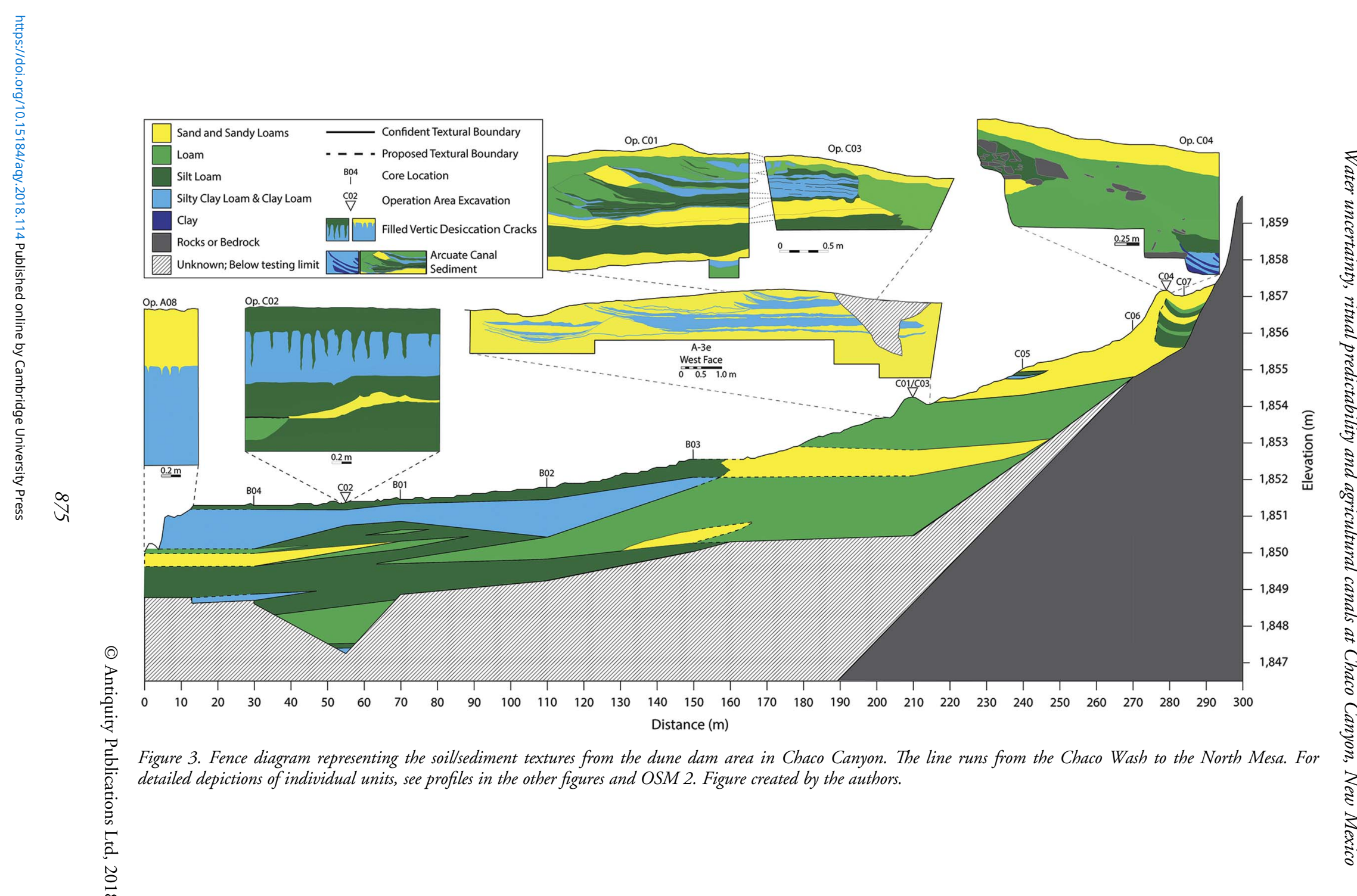


several canal profiles running between the Chaco Wash and the North Mesa. The most revealing profile (Op. C01/C03) from our recent work consists of two $2 \times 1 \mathrm{~m}$ excavation units that re-exposed a set of canals originally revealed in Vivian's A-3e profile (1971) (Figure 4). Vivian's long trench also exposed a smaller channel immediately to the south (Figure 5). The lowest unit (K) identified in Op. C01 comprises sterile sands and siltsprobably a former floodplain surface. Unit $\mathrm{K}$, underlying the smaller channel visible in Vivian's profile, produced an OSL age of AD 900 \pm 100 (OSM 3).

The smaller channel is a natural shallow extension of a rincon drainage (an incised, erratically flowing seasonal channel pouring off the flanks of an exposed bedrock mesa) extending onto the floodplain that was culturally modified by berm construction, or an early opportunistically constructed canal. Unit $J$ is the first fluvial deposition layer encountered in Op. C01 within a second larger, more recently constructed canal. The creation of this canal suggests increasing water demands tied to agricultural intensification. In Vivian's excavation (1971), the southern margin of the initial phase of the larger canal was revealed as a $0.5-6 \mathrm{~m}$ high sandy berm with a clay cap. This same berm forms the northern margins of the adjacent smaller channel; the two canals may have been briefly contemporaneous. Most of the larger channel, however, formed after the abandonment of the smaller channel. Gravel and sand deposits within the smaller channel indicate that it experienced a period of high-energy flow prior to abandonment. Post-abandonment, the smaller channel infilled further, and the southern berm of the larger northern canal was elevated.

Unit I in the large canal consists of stratified fluvial sands deposited during a period of moderately swift water movement. This was followed by a prolonged period of well-controlled water flow during which stratified clay and clay loam fluvial sediments were laid down (units G-1 \& G-2). The overlying unit F comprised cross-bedded silts and sands resulting from aeolian deposition - a period during which the canal was not in use. The final aeolian deposit was a distinct brittle silt cap (unit E), which was absent at the southern extreme of Op. C01, where later scouring probably removed it along with a small portion of unit $\mathrm{F}$. The scouring marked the renewal of water flow, which then resulted in the successive deposition of stratified silty fine sand of unit D. Unit D produced an OSL age of AD 900 \pm 100 (OSM 3).

Subsequently, the canal was modified by the construction of a series of successive berms (units C-3 \& C-4). These berms significantly narrowed the width of the canal as the elevation of the floor continued to rise via aggradation-chiefly from the clay loam sediments of units C-1 and C-2 that indicate slower water flow. Vertically positioned flagstone slabs to divert water were also encountered at this level. These probably served to spread irrigation waters (Figure 6). Unit C-4 produced an OSL age of AD $1000 \pm 100$ and an AMS radiocarbon age of 985 \pm 20 BP (UCIAMS-167243: AD 997-1150 at 95.4\%; date modelled in CALIB v.7.10, using the CALIB radiocarbon calibration curve) (Stuiver et al. 2017) (OSM 3-4). The narrowing of the canal and return to clay-rich sediments (units C-1 \& C-2) probably indicates efforts to maintain flow as water availability dropped.

The use-history of the canal becomes increasingly hard to discern in the uppermost parts of Ops. C01/C03 due to later erosion and soil-formation processes, including bioturbation (e.g. rodent burrows, ant nests and plant roots). Thin lenses of clay loam fluvial sediment (the uppermost examples of C-1 and C-2) were embedded within a narrowing channel formed of silt and sand (unit C-3). The increased narrowing further suggests greater difficulty in harnessing (C) Antiquity Publications Ltd, 2018 

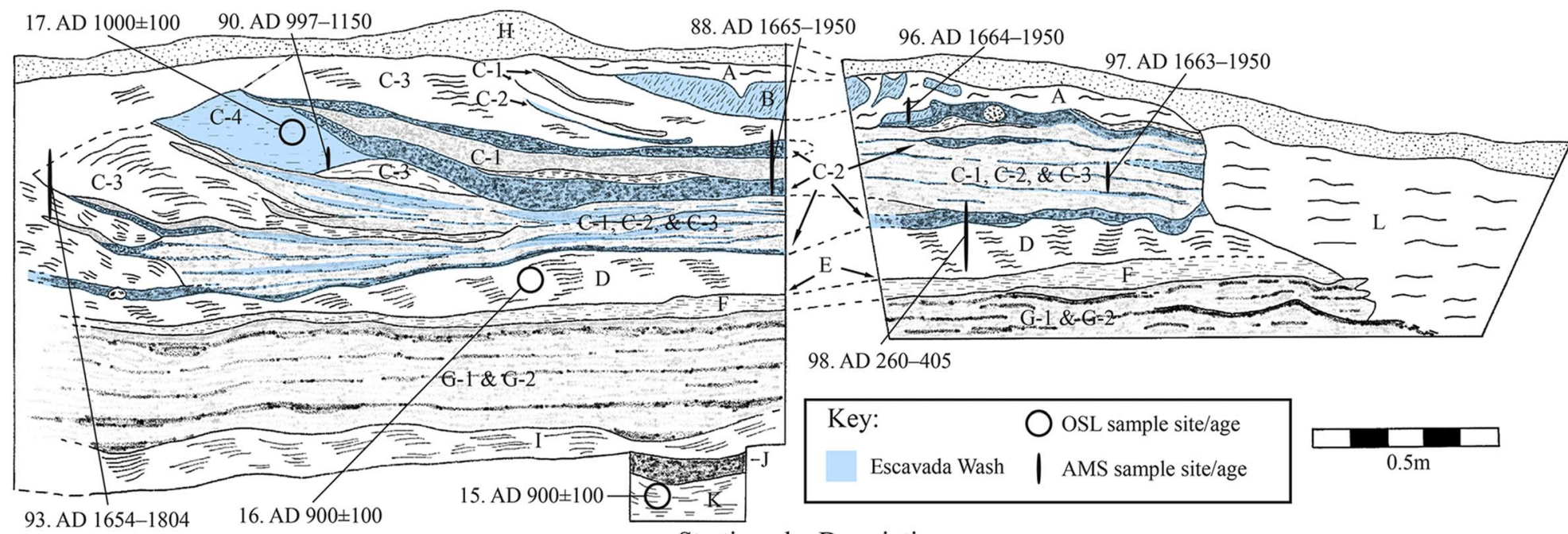

98. AD $260-405$

\section{Key: $\quad$ OSL sample site/age \\ Escavada Wash | AMS sample site/age}

Stratigraphy Description:

H. Very Pale brown (10YR 7/3) granular fine sandy silt.

A. Brown (10YR 5/3) finely stratified silt loam grading downward into finely stratified fine sandy loam and sandy loam (with coarser sand in more recent channel fill).

B. Dark greyish brown (10YR 4/2) clay loam; subangular blocky to platy structure; fractured into separate "blocks" towards east.

C-1. Light grey (10YR 7/2) clay loam; finely stratified.

C-2. Greyish brown (10YR 5/2) clay loam; finely stratified.

C-3. Light yellowish brown (10YR6/4) fine sandy silt; finely stratified.

C-4. Light yellowish brown (10YR6/4) fine sand; massive. Forms berm-like feature.

D. Light yellowish brown (10YR6/4), but variegated with lighter and darker zone

E. Very pale brown $(10$ YR $7 / 3)$ silt. Continuous thin $(>1 \mathrm{~cm})$ silt cap.

F. Pale brown (10YR6/3), but variegated; fine sandy silt; finely stratified.

G-1. Light grey (10YR7/2) clay loam; finely stratified.

G-2. Dark greyish brown (10YR4/2) clay loam; finely stratified.

I. Light yellowish brown (10YR 6/4) silty fine sand; weakly stratified.

J. Dark greyish brown (10YR4/2) clay loam; finely stratified.

Figure 4. Profile of Ops. CO1/CO3 showing stratigraphy, sediment sourcing (uncoloured layers sourced to the Chaco Wash/rincons), and the locations of OSL/AMS ages. The numbers next to the OSL ages refer to Chaco 2015-XX in OSM 3. The numbers next to the AMS ages refer to DD-XX in OSM 4. Figure created by the authors. 
Profile Views of Feature in Op. C01, Facing West/Southwest
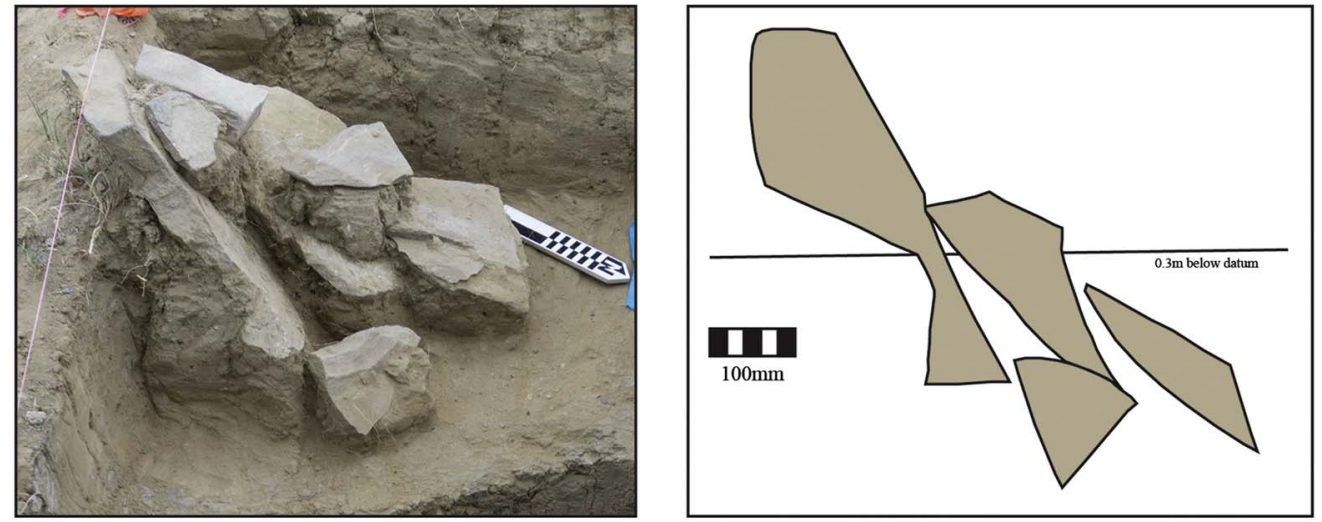

Plan View of Feature in Op. C01, Facing North/Northwest

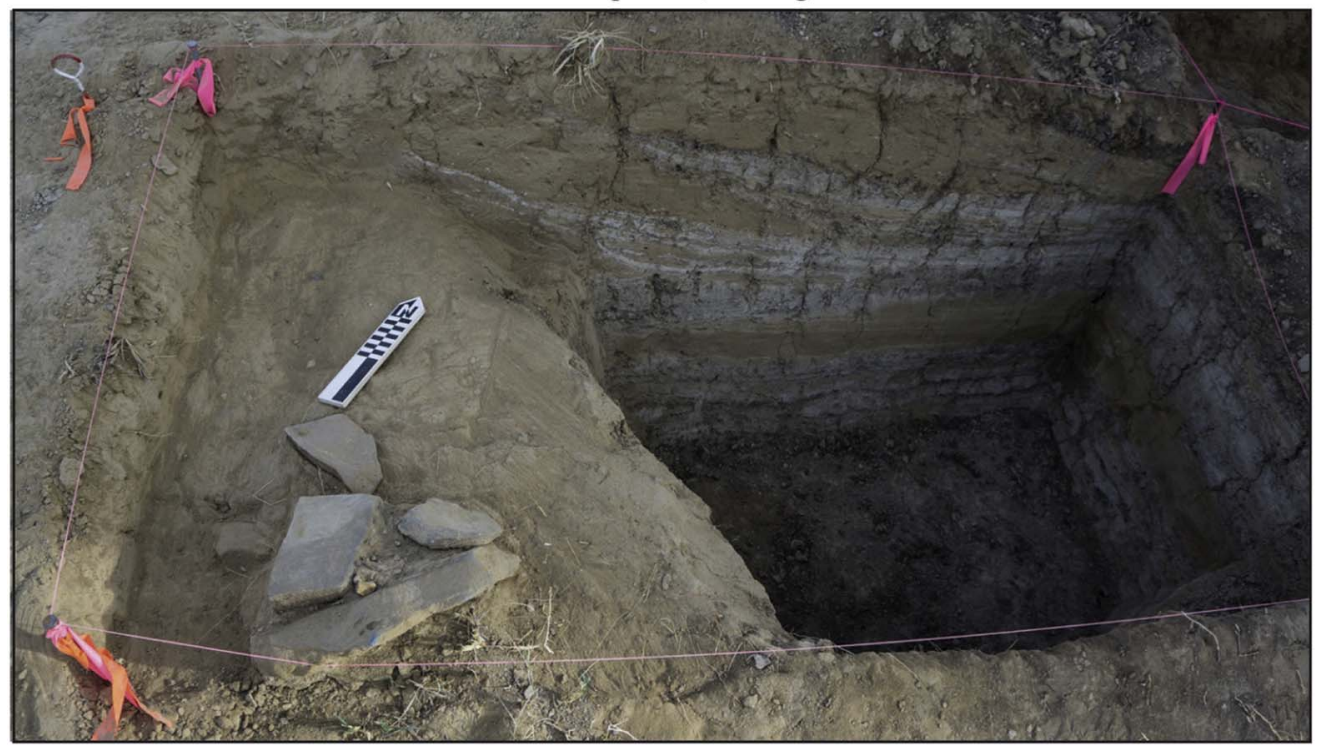

Figure 6. Stone feature on the edge of the canal sediments in Op. C01. Figure created by the authors.

water. The last fluvial deposit within the canal is the highly pedogenically altered unit $\mathrm{B}$ (or those processes in this case by which recently relocated sediments now resemble organically rich soils), possibly representing a final effort to harness water. Unit L, located on the edge of Op. C03, indicates the destruction of the canal by erosion. Whether this erosion occurred at canal abandonment, or later, is unclear.

\section{Canal source and use-histories}

Given the range of OSL ages from the three sampled areas in Op. C01, dating the big canal and its history is imprecise. It is, however, indisputably an Ancestral Puebloan feature created

(C) Antiquity Publications Ltd, 2018 
sometime after $\mathrm{AD} 800$, and was in use possibly as late as the early twelfth century. The similarity of the three OSL samples and their overlapping age ranges suggest that the system evolved fairly quickly, perhaps in as little as a century. The young AMS ages from Ops. C01/C03 (Figures 4 \& 6) are disputable given the significant bioturbation in the upper units of the profile. The old radiocarbon AMS age was derived from charcoal probably introduced by water flow through the channel. To assess whether water sources can be distinguished, modern alluvium and waters collected from the Chaco Wash, North Mesa rincons and the Escavada Wash were analysed with energy-dispersive X-ray fluorescence spectrometry (ED-XRF), and strontium isotopes $\left({ }^{87} \mathrm{Sr} /{ }^{86} \mathrm{Sr}\right.$ ) were measured. ED-XRF revealed two distinct signatures: the Escavada Wash and Chaco Canyon, the latter comprising the samples collected from the Chaco Wash and the North Mesa rincons. Comparing these signatures to sediment samples collected from Ops. C01/C03 indicates that the majority of the layers derive from the Chaco Wash or the adjacent rincons; three layers, however, source to the Escavada Wash, suggesting that the canals tapped multiple water sources over time (OSM 5). Unit C-2, which is closely interbedded with unit C-1, sources to the Escavada Wash, and represents a period during which multiple sources were tapped, probably in quick succession. These deposits were deliberately embanked by relocating mixed matrices from within the canal or the nearby Escavada Wash (unit C-4). Unit B-the final fluvial deposit within the canal—also sources to the Escavada Wash, perhaps denoting a last attempt to harness this more dependable water source. Vivian (CHCU 55430 1971) suggested that the Escavada Wash was partially diverted up-canyon in this dune zone (Figure 1). Our ground-truth and LiDAR assessments indicate that such a diversion was possible, although the present linear dune blowing off the most western margins of the North Mesa and down the Escavada Wash obscures any direct evidence for such a diversion.

Strontium isotope data also corroborate multiple diversion strategies. Waters collected from the Chaco and Escavada Washes just above their confluence are isotopically distinct, with two nearby sampled rincons having intermediate ratios (OSM 6). A similar isotopic range is observed in core sediments that were collected from the edge of the bend in the Chaco Wash. At a depth of $2.09-2.19 \mathrm{~m}$, sediments isotopically resemble the Chaco Wash. At depths of $0.9-1 \mathrm{~m}$ and $0.4-$ $0.5 \mathrm{~m}$, however, sediments have higher ratios, suggesting an influx of material from the Escavada Wash and possibly the rincons— a similar stratigraphic sourcing history to the well-defined canal deposition discussed above. Future isotopic analyses of canal sediments may further disentangle phases of water diversion and sediment deposition.

\section{Other canals}

Waters from both the Chaco Wash and the North Mesa rincons were probably channelled by the Ops. C01/C03 canals. Today, water intake from the Chaco Wash appears unfeasible, but its current incised course-about $7 \mathrm{~m}$ below and $150 \mathrm{~m}$ to the south-west of Ops. C01/C03 - probably differs from that in the past, given the dynamic environmental setting. A LiDARderived hillshade image of the dune dam area indicates several probable canal paths traversing the local landscape (Figure 7). The LiDAR-derived contour lines at 1856 and $1854 \mathrm{~m}$ demonstrate the hydrological plausibility of canals feeding from either the Escavada or Chaco Washes (Figure 1). These paths follow gentle gradients of about 1 per cent; the precise gradient of any canal, however, is difficult to determine due to the disruptive effects of

(C) Antiquity Publications Ltd, 2018 

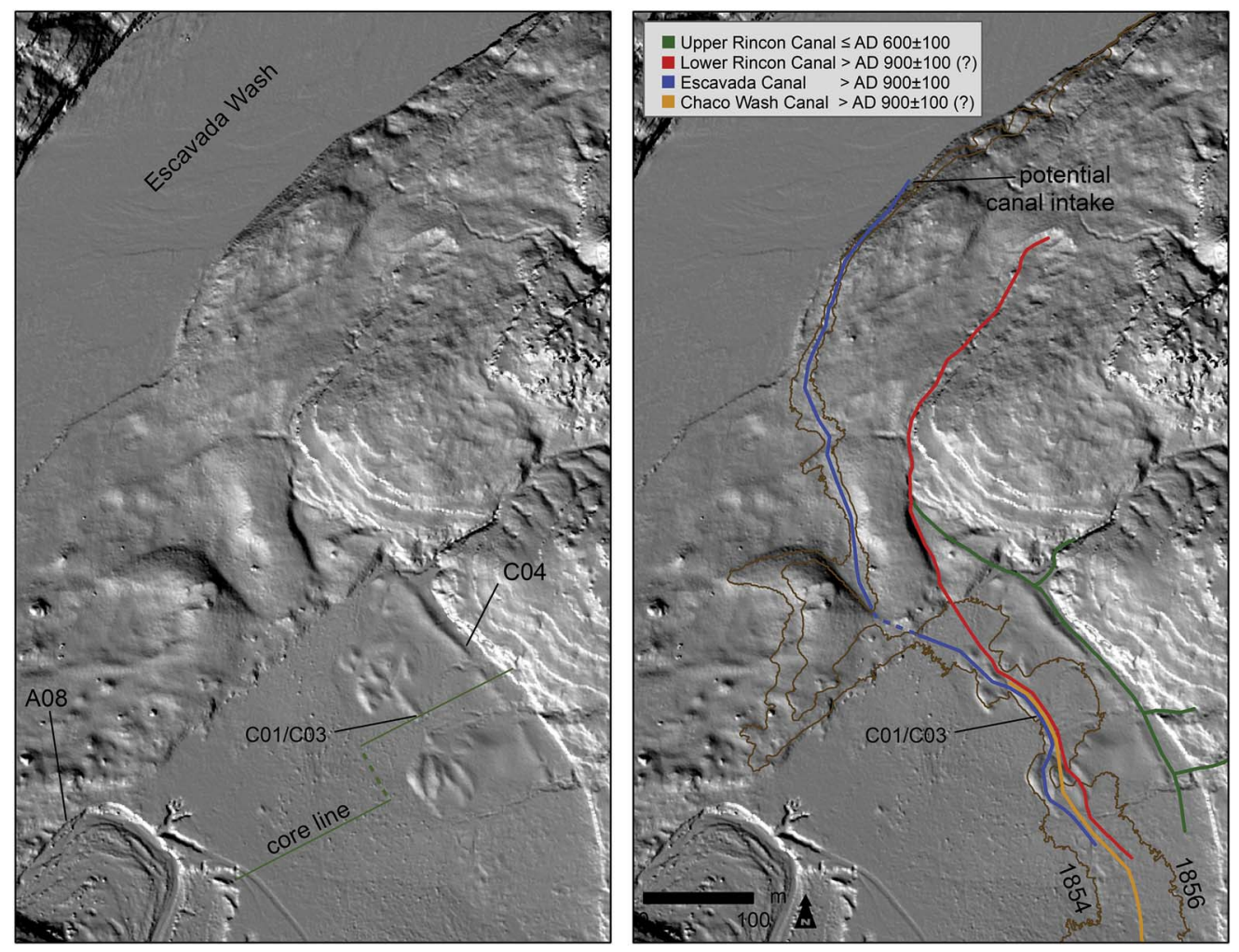

Figure 7. Left: LiDAR-derived hillshade image showing our operations and the ridges in the alluvial plain, which carry the canal remnants. Right: hypothesised canals and LiDAR-derived elevation contour lines $1856 \mathrm{~m}$ and $1854 \mathrm{~m}$ ), which bracket hydrologically plausible canals feeding from either the Escavada or Chaco Washes. Figure created by the authors.

erosion and aggregation, and the presence of stacked canal segments within our exposed profile. The breadth of the canals located in our excavation suggests adequate amounts of water for agriculture, possibly involving the diversion of a significant flow from the Chaco Wash from farther upstream (OSM 7). While canals connecting Ops. C01/C03 to the Chaco Wash would be long, a probably contemporaneous canal of similar length located at Kin Bineola (a great house $30 \mathrm{~km}$ away), ran for over a kilometre to connect an intermittent stream to associated fields (Lyons 1977; Vivian 1990: 47, 70, 377; Vivian \& Palmer 2002). Additionally, excavation has revealed a canal (Op. E02) along the edge of the Chaco Wash, near the anticipated intake for those documented in Ops. C01/C03 (Figure 8). While these canal profiles cannot be definitively linked, they suggest an extensive local canal system.

The LiDAR-derived hillshade image (Figure 7 ) also reveals a canal running along the foot of the North Mesa, a portion of which was exposed by a $2 \times 1 \mathrm{~m}$ excavation (Figure 9). Op. $\mathrm{C} 04$ contains evidence of canal deposits dating to the Late Basketmaker period (AD 500750 ), based on an OSL age of AD 600 \pm 100 (OSM 3). The location of this canal makes the rincons the most probable source and supports Vivian's (1972) assessment that most known stone-lined irrigation features within the canyon are associated with North Mesa rincon sources (see Wills et al. 2016). Vivian (1990) documented sandstone-slab head gates and 

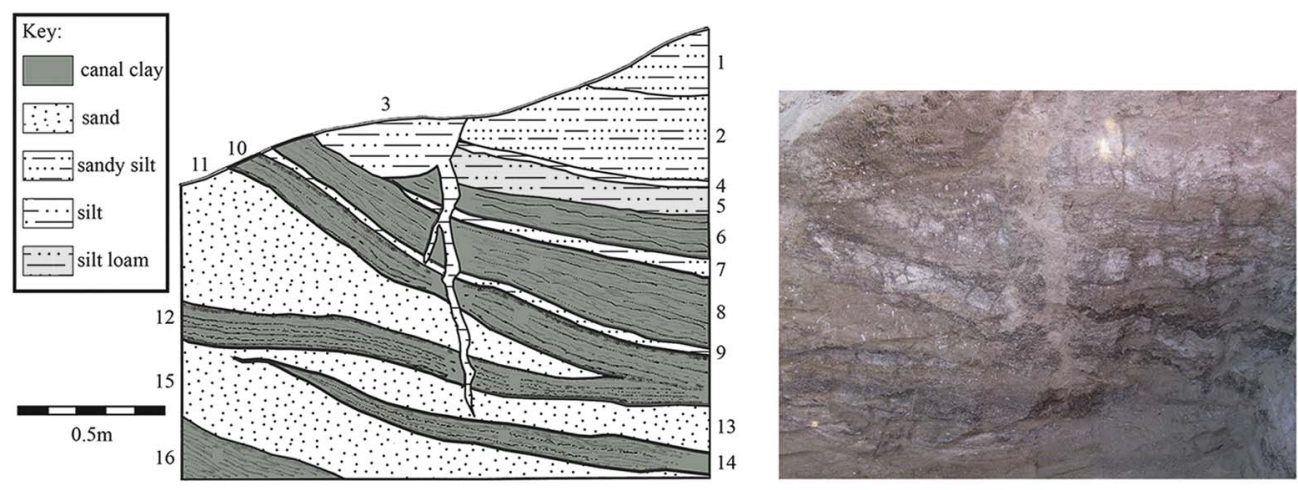

Stratigraphy Description:

1. Light yellowish brown (10YR 6/4) granular fine sandy silt

2. Yellowish brown (10YR 5/4) slightly firm, granular fine sandy silt with scattered small carbonate nodules (moderately effervescent)

3. Dark yellowish brown (10YR 4/6) but slightly mottled silt; appears to be fill (cast) in former tree root bole - though could be fill in a deep old wagon wheel or tire rut. Apparent root cast extends about $0.5 \mathrm{~m}$ below this feature

4: Light grey (10YR 7/2) firm, but friable silt

5: Brown (10YR 5/3) loamy silt with widely scattered small carbonate nodules (moderately effervescent); weakly stratified

6: Light grey (10YR7/2) clay loam; finely stratified with a few darker bands; widely scattered small carbonate nodules (moderately effervescent), easily friable

7: Light yellowish brown (10YR6/4) silty fine sand; granular; widely scattered small carbonate nodules (moderately effervescent)

8: Pale brown (10YR7/3) clay; strongly laminated, interstratified with frequent dark brown (10YR3/3) clay bands and a few thin, light yellowish brown (10YR6/4) sand layers; frequent small carbonate nodules occurring in irregular groupings
9. Light yellowish brown (10YR6/4) silty fine sand; granular

10. Closely interstratified dark brown (10YR3/3), and pale brown (10YR7/3) clay, and light yellowish brown (10YR6/4) silty fine sand

11. Yellowish brown (10YR5/6) fine sand; massive, but friable; frequent small carbonate nodules (moderately effervescent)

12. Closely interstratified dark brown (10YR3/3), and pale brown (10YR7/3) clay, and light yellowish brown (10YR6/4) silty fine sand

13. Dark yellowish brown (10YR4/6) fine to medium sand; stratified; massive, but friable

14. Brown (10YR4/2) clay; strongly laminated, with two interstratified yellowish brown sand lenses

15. Brownish yellow $(10$ YR6/5) fine sand, weakly stratified with a few thin dark clay lenses

16. Brown (10YR4/2) clay; laminated.

Note: all units continue into and across north wall of the excavation, except

Unit 3. Excavation was into Rincon wall and did not have south or east walls.

Clearing of Rincon cut north of E02 showed the continuity of the strata

described above further under the linear ridge.

Figure 8. Profile of $O p$. E02 showing the partial outline of a canal near the possible upstream intake along the edge of the Chaco Wash. Figure created by the authors.

canal segments around $1 \mathrm{~km}$ up-canyon from Op. C04. The presence of multiple canal segments that fed from different sources within close proximity of one another supports the existence of a highly flexible and developed local system for allocating water.

\section{Roberts Great House}

Although the focus of this article is the lower far reaches of the Chaco Wash, our work at Roberts Great House, located near Wijiji, also accentuates the highly dynamic setting (see Roberts 1926) (Figure 1). This incomplete great house was covered by nearly a metre of sediment, and the later cut of an adjacent arroyo flanking the architecture has exposed the structure's deeply eroded western margins. Our OSL ages indicate that the great house was buried soon after its foundations were constructed around the twelfth century (OSM 8). More dramatic evidence of marked alluviation is apparent within another arroyo profile from the same rincon, slightly south-east of Roberts Great House (Figure 10). Near the head of this arroyo cut, our profiling and dating revealed an early ninth-century pithouse buried under approximately $2 \mathrm{~m}$ of slope wash. The upper reaches of the profile exposed runnels or channels suggestive of irrigation that was probably coeval with the great house centuries later. While nuanced histories of canal segments were not revealed in this portion of the canyon, multiple agricultural strategies were probably employed to support local populations.

(C) Antiquity Publications Ltd, 2018 


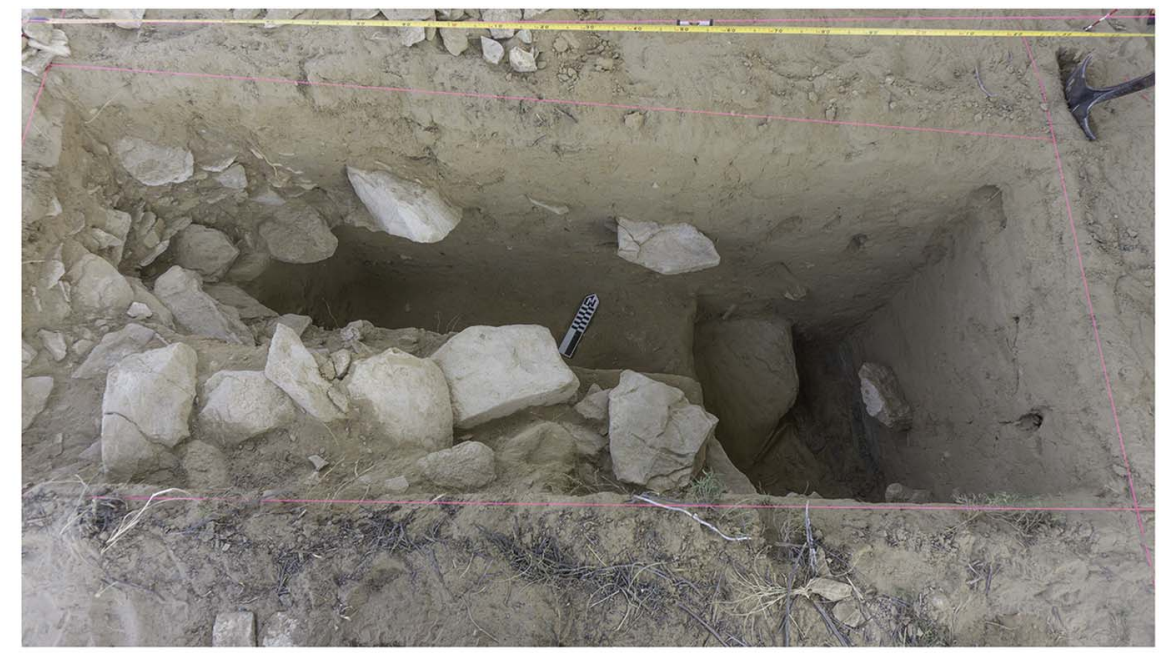

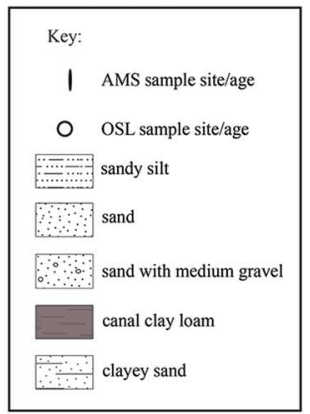

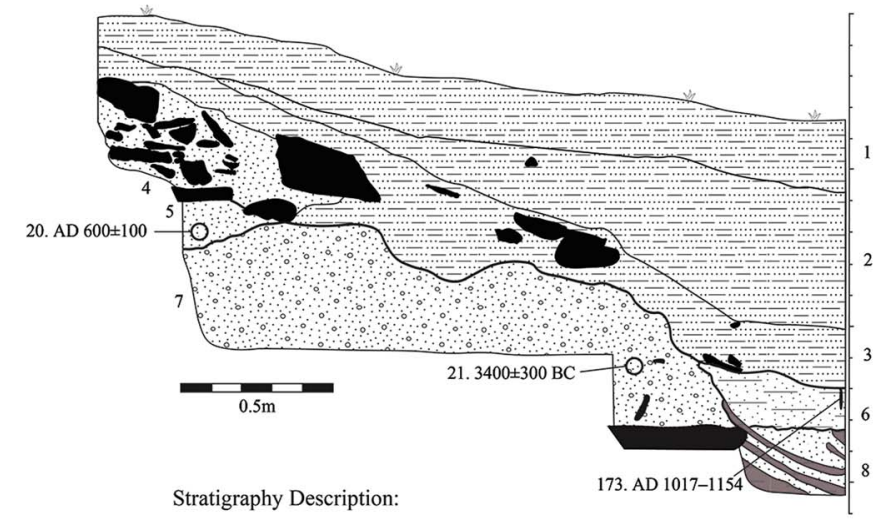

1. Light yellowish brown (2.5Y $6 / 3)$; fine sand and silt; gradual boundary 2. Light yellowish brown (2.5Y 6/3); fine sand and silt with up to $5 \%$ coarse sand and pebbles up to $3 \mathrm{~cm}$ in diameter; greater development of massive structure relative to above; rodent burrows and insect traces visible through unit

3. $(2.5 \mathrm{Y} 6 / 3)$; Same finer materials as Unit 2 with presence of stones, cobbles, and gravels eroded or tumbled out of the wall/berm reinforcement collapse as interpreted from orientation tilted toward the east

4. Light olive brown (2.5Y 5/3); sandy matrix with higher organic matter content; some clay laminae under stones; in fill between rocks in wall/berm reinforcement

\footnotetext{
5. Light yellowish brown (2.5Y 6/4); sandy matrix directly underlying stones in Unit 4 pinches out in north profile to the east

6. Light olive brown (2.5Y 5/3); clayey sand infilling old canal depression; very few to no stones; no deposition features

7. Light yellowish brown (2.5Y 6/4); fill material of silty sand with $5 \%$ small to medium sized gravels; little to no consistent fragment orientation

8. Dark grey clay laminae beds (2.5Y $4 / 1)$ with thin light yellowish brown sandy intervening laminae $(2.5 \mathrm{Y} 6 / 4)$
}

Figure 9. Plan and profile views of Op. CO4 illustrating a Basketmaker III canal along the edge of the rincons. The numbers next to the OSL ages refer to Chaco 2015-XX in OSM 3. The numbers next to the AMS ages refer to DD$X X$ in OSM 4. Figure created by the authors.

\section{Canals and agriculture}

Within the dynamic setting of Chaco Canyon, our recent excavations and analyses demonstrate the exploitation of multiple water sources. Water from these canals could certainly have been used for domestic purposes, but agriculture best explains their location within the floodplain. Early canals probably gathered and directed runoff from the nearby rincons, as exemplified by the canal in Op. C04. Later, waters from the Escavada and Chaco Washes-in combination with rincon waters-were diverted for agricultural use into more 


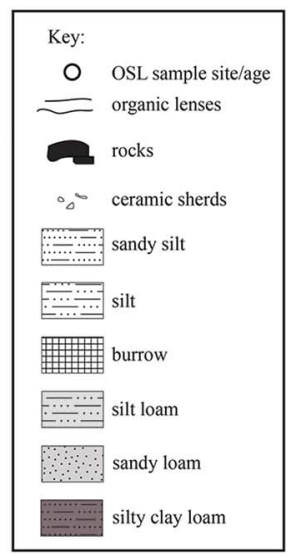

Stratigraphy Description:

1. Brown (7.5YR 4/4) granular fine sand and silty sand; small amounts of fibrous organic matter; abundant rootlets

2. Strong brown (7.5YR 5/6) thinly stratified fine sand and silt; compact and granular structure

3. Dark brown (7.5YR 3/2) organic sandy silt; fine crumb to granular structure; abundant rootlets

4. Brown (7.5YR 5/3) sandy silt; very fine crumbs; scarce rootlets

5. Light brown (7.5YR 6/3) dense silt (fluvial mud)

6. Brown (7.5YR 5/3) finely stratified silt and fine to medium sand

lenses; compact granular structure; widely scattered charcoal fragments

7. Light brown (7.5YR 6/4) lightly stratified, indurated and massive, but friable silty fine sand; widely scattered calcium carbonate concretions

8. Brown (7.5YR 5/3) finely stratified silty sand; widely scattered charcoal flecks

9. Light brown (7.5YR 6/3) dense silt (fluvial mud); includes intrusive channel filled with water-laid sediments (see 13a)

10. Brown (7.5YR 5/3) lightly stratified large hard crumb to massive, but friable sandy silt; widely scattered charcoal fragments and secondary sherds; the base of this unit is formed by apparent field furrows

11. Light brown (7.5YR 6/3) lightly stratified massive, but friable sandy silt

12. Brown (7.5YR $5 / 3)$ weakly stratified sandy silt; widely scattered ceramic sherds; sandstone bal

13. Pinkish grey (7.5YR 6/2) massive silt loam; abundant charcoal fragments and secondary sherds; includes intrusive channel filled with water-laid sediments (see 13a)

13a. Light grey (7.5YR 7/1) strongly stratified, water-laid silt filling channel; the base of this unit is formed by apparent field furrows

14. Pinkish grey (7.5YR 6/2) blocky clay (probably created from channel seepage)

15. Brown $(7.5$ YR $5 / 2)$ hard crumb to massive silt loam

16. Brown (7.5YR 5/4) massive, but friable fine sandy loam; widely scattered charcoal fragments

17. Pink (7.5YR 7/4) indurated massive silt loam; widely scattered charcoal fragments

18. Pithouse fill. Non-uniform. Strongly stratified brown and light brown medium to fine sand and silt; includes zone of oxidized sediments between 1.52 and $1.62 \mathrm{~m}$; increasing charcoal with depth

18a. Pithouse interior fill. Strongly stratified brown and light brown medium to fine sand and silt; abundant charcoal fragments and ceramic sherds

19. Pithouse interior fill. Strongly stratified brown and light brown medium to fine sand and silt; abundant charcoal fragments and ceramic sherds

20. Embedded within Unit 19; Dark grey (7.5 4/1) massive, but friable silt loam; abundant coal fragments

21. Buried topsoil horizon; very dark grey (7.5YR 3/1) blocky to massive silt loam; infilled root channels within ped structure

22. Brown (7.5YR 5/3) massive fine sandy loam

23. Light brown (7.5YR 6/3) massive loamy silt (apparently top of thick horizon)

Figure 10. Op. 100 profile located at the east end of Chaco Canyon showing rapid alluviation. The numbers next to the OSL ages refer to Chaco 2014-XX in OSM 3. The numbers next to the AMS ages refer to DD-XX in OSM 4. Figure created by the authors.

complex systems of artificial channels or earthen canal segments. These canals were stacked or reused during the ninth and tenth centuries, with their elevated, infilled courses possibly reused during the historical Navajo period (Figure 4). When added to Vivian's evidence (1990) for stone-slab-lined canal segments and diversion gates, it is apparent that a highly complex set of risk-aversion strategies was in place that utilised water from multiple independent sources. While our fieldwork emphasises the use of canal irrigation within Chaco Canyon, this represents just one piece of a multifaceted agricultural management system that was tailored to the local environmental conditions (Vivian \& Watson 2015).

(C) Antiquity Publications Ltd, 2018 


\section{Discussion and conclusions}

Evidence from our fieldwork confirms the long-suspected operation of canal irrigation in portions of Chaco Canyon between AD 800 and 1130. Quick social responses to the dynamic setting were necessary to harness multiple water sources through the canal system below Peñasco Blanco-probably drawing upon labour provided by occupants of the great houses and the numerous small sites throughout the canyon. To combat environmental unpredictability and coordinate the construction and maintenance of the hydrological infrastructure, social responses must have been structured through leaders, whose actions reduced risk and uncertainty.

Most explanations for the management of food production within Chaco concentrate on the occupants of the great houses, as these sites were located close to desirable agricultural settings (e.g. Dorshow 2012; Wills \& Dorshow 2012; cf. Fendon 1959). North American ethnographic research suggests that the societal emphasis on horticulture - often involving substantial female labour investment-correlates with matrilineality and matrilocal residence (Driver \& Massey 1957: 432). Ware (2014) also suggests that ethnographic explanations for both matrilineality and matrilocality revolve around a localised agricultural base controlled by women (cf. Steward 1955). Supporting the potential link between agricultural production and matrilineality, a recent archaeogenomic study of a rich burial cluster from within Pueblo Bonito identified a matrilineal connection among the burials. These date from the founding of the great house and continue throughout much of its occupation (Plog \& Heitman 2010; Kennett et al. 2017). The existence of prominent matrilineal groups who could oversee, if not direct, the farming efforts may explain the successful adaptation of the canal system to highly uncertain environmental conditions. This association persists in the U.S. Southwest today, as ties between Pueblo ritual leaders and water management are recorded ethnographically (e.g. Parsons 1939; Ortiz 1969: 106).

Additional support for the linkage between ritual leadership, matrilineality and watermanagement systems tied to agricultural resources can be found in the material assemblages within or near the Pueblo Bonito burial cluster. In addition to a range of non-local materials suggesting long-distance ties and ritual authority (Neitzel 2003; Crown \& Hurst 2009; Watson et al. 2015), many of the materials are ethnographically documented symbols of moisture and fertility throughout the Southwest, such as turquoise and frog/tadpole effigies (Plog 2003, 2011). These symbols suggest that links to water and agricultural success were important aspects of ritual practice tied to the elite occupants of great houses. Ritual is intimately intertwined with economics and politics in the Pueblo Southwest (e.g. Fowles 2013), and potentially marked or legitimised the matriline's authority in water-management decisions. Ritual practice, economic access and political authority tied to moisture and fertility almost certainly allowed for the deployment and management of a labour force that responded quickly to environmental change. The centralisation of leadership may, in part, have sustained the Chaco social system by establishing certainty in the face of unpredictable environmental factors.

Many forces surely triggered the cascading social developments within Chaco Canyon (Watson et al. 2015; Kennett et al. 2017). The dynamic interplay of rapid sedimentation, reciprocal erosional processes and the necessity of monitoring and containing soils for cropping must have markedly influenced how labour deployed. The social context for this dynamism necessitated attempts to reduce risk in order to produce an adequate food supply. 
Due to the erratic rainfall patterns, diverse strategies were employed to increase the predictability of water availability for farming. Our data suggest that rincon runoff sources were initially diverted, while more formal distributary canalisation sourced from both nearby washes developed later as Puebloan infrastructure advanced. Nevertheless, uncertainty was always a concern. The development of social controls to monitor diverse water sources and deploy labour in order to maintain established water-management systems was necessary to ensure quick responses to the dynamic local environmental conditions-responses that were fundamental to the success of Chaco society.

\section{Acknowledgements}

Funding from the University of Cincinnati Research Council, the Charles Phelps Taft Foundation, and the Deans of the College and Graduate School of Arts and Sciences at the University of Virginia and the University of Cincinnati supported this study. We are especially grateful to the National Park Service, Chaco Culture National Historical Park, the New Mexico Office of Archaeological Studies, the Navajo Nation and members of the American Indian Advisory Council to the National Park Service. This work was accomplished under U.S. department of the interior permit 15-CHCU-01. We are equally grateful to Gideon Bartov and Tom Johnson (UIUC) for assisting with the Sr isotope analysis. We also owe special thanks to Warren Huff, Venicia Slotten, Jessica Thress, Josh Miller and Douglas Dvoracek for their assistance and insights. Our team appreciates the careful assessment from the editors at Antiquity and the external reviewers, and extends special thanks to Barbara Mills for her invitation to submit to this recent research on Chaco Canyon in this special section.

\section{Supplementary material}

To view supplementary material for this article, please visit https://doi.org/10.15184/aqy.2018.114

\section{References}

Benson, L.V. 2016. The Chuska Slope as an agricultural alternative to Chaco Canyon. Journal of Archaeological Research 16: 456-71. https://doi.org/10.1016/j.jasrep.2016.10.017

Bryan, K. 1954. The geology of Chaco Canyon, New Mexico in relation to the life and remains of the prehistoric peoples of Pueblo Bonito (Smithsonian Miscellaneous Collections 122). Washington, D. C. Smithsonian Institution.

CHCU 55430. 1971. Escavada Wash water control system, plan and sections of Escavada Wash canal, w/ gates, spillway. National Park Service, Chaco Culture National Historical Park, Gwinn Vivian Collection (0030)-CHCU 55430 .

Cordell, L.S., H.W. Toll, M.S. Toll \& T.C. Windes. 2008. Archaeological corn from Pueblo Bonito, Chaco Canyon, New Mexico: dates, contexts, sources. American Antiquity 73: 491-511. https://doi.org/10.1017/S0002731600046837
Crown, P.L. \& W.J. Hurst. 2009. Evidence of cacao use in the preHispanic American Southwest. Proceedings of the National Academy of Sciences of the USA 106: 2110-13. https://doi.org/10.1073/pnas.0812817106

DeAn, J.S. \& G. FunKhouser. 2002. Dendroclimatology and fluvial chronology in Chaco Canyon, in E.R. Force, R.G. Vivian, T.C. Windes \& J.S. Dean (ed.) Relation of 'Bonito' paleo-channels and base-level variations to Anasazi occupation, Chaco Canyon, New Mexico (Arizona State Museum Archaeological Series 194): 3941. Tucson: Arizona State Museum.

Dorshow, W.B. 2012. Modeling agricultural potential in Chaco Canyon during the Bonito Phase: a predictive geospatial approach. Journal of Archaeological Science 39: 2098-115. https://doi.org/10.1016/j.jas.2012.02.004

Driver, H.E. \& W.C. Massey. 1957. Comparative studies of North American Indians. Transactions of the American Philosophical Society 47: 165-460. https://doi.org/10.2307/1005714 
Fendon JR, E.N. 1959. Agricultural potential and the development of cultures. Southwestern Journal of Anthropology 15: 1-19. https://doi.org/10.1086/soutjanth.15. 1.3629000

Force, E.R., R.G. Vivian, T.C. Windes \& J.S. DeAn (ed.). 2002. Relation of 'Bonito' paleochannels and base-level variations to Anasazi occupation, Chaco Canyon, New Mexico (Arizona State Museum Archaeological Series 194). Tucson: Arizona State Museum.

Fowles, S. 2013. An archaeology of doings: secularism and the study of Pueblo religion. Santa $\mathrm{Fe}(\mathrm{NM})$ : SAR.

Friedman, J.M., K.R. Vincent, E.R. Griffin, M.L. Scott, P.B. Shafroth \& G.T. Auble. 2014. Processes of arroyo filling in northern New Mexico, USA. Geological Society of America Bulletin 127(3-4): 621-40. https://doi.org/10.1130/B31046.1

HaLL, S.A. 1977. Late Quaternary sedimentation and paleoecologic history of Chaco Canyon, New Mexico. Geological Society of America Bulletin 88: 1593-618. https://doi.org/10.1130/0016-7606(1977) 88<1593:LQSAPH > 2.0.CO;2

-2010 . New interpretations of alluvial and paleo-vegetation records from Chaco Canyon, New Mexico, in J.E. Fassett, K.E. Zeigler \& V. Lueth (ed.) New Mexico Geological Society guidebook, $61^{\text {st }}$ Field Conference, Four Corners Country: 231-46. Socorro: New Mexico Geological Society.

Haussner, E.A. 2016. A revised Middle to Late Holocene alluvial chronology of Chaco Canyon, New Mexico. Unpublished MS dissertation, University of Cincinnati.

Heitman, C.C. \& S. Plog (ed.). 2015. Chaco revisited: new research on the prehistory of Chaco Canyon, New Mexico. Tucson: University of Arizona Press.

JaCKsON, W.H. 1878. Report on the ancient ruins examined in $1875-1877\left(10^{\text {th }}\right.$ Annual Report, U.S. Geologic and Geographic Survey of Territories for the Year 1878). Washington, D.C.: Government Printing Office.

Kennett, D.J., S. Plog, R.J. George, B.J. Culleton, A.S. Watson, P. Skoglund, N. Rohland, S. Mallick, K. Stewardson, L. Kistler, S.A. LeBlanc, P.M. Whiteley, D. Reich \& G.H. Perry. 2017. Archaeogenomic evidence reveals prehistoric matrilineal dynasty. Nature Communications 8. https://doi.org/10.1038/ncomms14115

Lekson, S.H. (ed.). 2006. The archaeology of Chaco Canyon: an eleventh-century Pueblo regional center. Santa Fe (NM): SAR.

Love, D.W. 1980. Quaternary geology of Chaco Canyon, northwestern New Mexico. Unpublished $\mathrm{PhD}$ dissertation, University of New Mexico.

Love, D.W., M.L. Gillam, L.V. Benson, R. Friedman, P.L. Miller \& K.R. Vincent. 2011. Geomorphology, hydrology, and alluvial stratigraphy in lower Chaco Canyon do not support the possible existence of prehistoric sanddammed ephemeral lakes. New Mexico Geology 33: 107-23.

Lyons, T.R. 1977. Notes concerning test excavations of the linear features adjacent to Tear Drop Mesa, Kin Bineola (Report prepared for Chaco Center). Albuquerque (NM): National Park Service.

McCool, J.P., S.G. Fladd, V.L. Scarborough, S. Plog, N.P. Dunning, L.A. Owen, A.S. Watson, K.J. Bishop, B.E. Crowley, E.A. Haussner, K.B. Tankersley, D. Lentz, C. CARr \& J.L. Thress. 2018. Soil salinity in discussions of agricultural feasibility for ancient civilizations: a critical review of the data and debate at Chaco Canyon, New Mexico. PLoS One 13: e0198290. http://doi.org/10.1371/journal.pone.0198290

McKenna, P.J. \& M.L. Truell. 1986. Small site architecture of Chaco Canyon (Publications in Archeology 18D, Chaco Canyon Studies). Santa Fe (NM): National Park Service.

Neitzel, J.E. (ed.). 2003. Pueblo Bonito: center of the Chacoan world. Washington, D.C.: Smithsonian Institution.

Ortiz, A. 1969. The Tewa world: space, time, being, and becoming in a Pueblo society. Chicago (IL): University of Chicago Press.

Parsons, E.C. 1939. Pueblo Indian religion. Chicago (IL): University of Chicago Press.

PLOG, S. 2003. Exploring the ubiquitous through the unusual: color symbolism in Pueblo black-onwhite pottery. American Antiquity 68: 665-95. https://doi.org/10.2307/3557067

-2011. Ritual and cosmology in the Chaco era in D. M. Glowacki \& S. van Keuren (ed.) Religious transformation in the late pre-Hispanic Pueblo world: 50-65. Tucson: University of Arizona Press. 
Plog, S. \& C.C. Heitman. 2010. Hierarchy and social inequality in the American Southwest, A.D. 800-1200. Proceedings of the National Academy of Sciences of the USA 107: 19619-26. https://doi.org/10.1073/pnas.1014985107

Roberts JR, F.H.H. 1926. Field notes (Report prepared for the National Geographic Society). Washington, D.C.: Smithsonian Archives of Anthropology.

Scarborough, V.L. 2003. The flow of power: ancient water systems and landscapes. Santa Fe (NM): SAR.

Scarborough, V.L., C. Carr, N. Dunning, S. Fladd, K. Bishop, J.P. McCoOL, E. Haussner, J. Thress, L. Owen, K. Tankersley, A. Watson \& S. Plog. 2016. An interdisciplinary investigation of climate and environmental change in an Early Puebloan society: permit

15-CHCU-01. Report prepared for National Park Service, Albuquerque.

Sebastian, L. 1992. The Chaco Anasazi: sociopolitical evolution in the prehistoric Southwest. Cambridge: Cambridge University Press.

Simpson, J.H. 1850. Journal of a military reconnaissance from Santa Fe, New Mexico, to the Navajo Country in 1849 (Report of the Secretary of War, $31^{\text {st }}$ Congress, $1^{\text {st }}$ Session, Senate Ex 64): 56-168.

STEWARD, J.H. 1955. Theory of culture change: the methodology of multilinear evolution. Urbana: University of Illinois Press.

Stuiver, M., P.J. Reimer \& R.W. Reimer. 2017. CALIB 7.1. Available at: http://calib.org (accessed 26 June 2018).

STURM, J.O. 2016. Using ground-penetrating radar to re-evaluate the Chetro Ketl field area in Chaco Canyon, New Mexico. Journal of Archaeological Science: Reports 7: 238-46. https://doi.org/10.1016/j.jasrep.2016.04.018

Tankersley, K.B., N.P. Dunning, J. Thress, L.A. Owen, W.D. Huff, S.G. Fladd, K.J. Bishop, S. Plog, A.S. Watson, C. Carr \& V.L. Scarborough. 2016. Evaluating soil salinity and water management in Chaco Canyon, New Mexico. Journal of Archaeological Research: Reports 9: 94-104. https://doi.org/10.1016/j.jasrep.2016.07.014

Vivian, G. \& T.W. Mathews. 1965. Kin Kletso: a Pueblo III community in Chaco Canyon, New
Mexico (Technical Series 6). Globe (AZ): Southwest Parks and Monuments Association.

Vivian, R.G. 1971. Chaco Canyon Water Control Project-general feature forms. National Park Service, Chaco Culture National Historical Park, Gwinn Vivian Collection (0030)CHCU-85920; VA 2064 Vivian II. Available at: http://www.chacoarchive.org/bibl_database/ cdi_accessions/show/20279?public=true (accessed 26 June 2018).

- 1972. Final technical report for prehistoric water conservation in Chaco Canyon. NSF grant no. GS-3100. National Park Service, Chaco Culture National Historical Park, Archives of the Chaco collection.

- 1974. Conservation and diversion: water control systems in the Anasazi Southwest, in T.E. Downing \& M. Gibson (ed.) Irrigation's impact on society (Anthropological Papers of the University of Arizona 25): 95-112. Tucson: University of Arizona.

- 1990. The Chacoan prehistory of the San Juan Basin. New York: Academic.

Vivian, R.G. \& D. Palmer. 2002. Kin Bineola water control system. Unpublished notes at Chaco Archive, Albuquerque.

Vivian, R.G. \& A.S. Watson. 2015. Reevaluating and modeling agricultural potential in the Chaco core, in C.C. Heitman \& S. Plog (ed.) Chaco revisited: new research on the prehistory of Chaco Canyon, New Mexico: 30-65. Tucson: University of Arizona Press. Vivian, R.G., C.R. van West, J.S. Dean, N.J. Akins, M.S. Toll \& T.C. Windes. 2006. Ecology and economy, in S.H. Lekson (ed.) The archaeology of Chaco Canyon: an eleventh-century Pueblo regional center: 45-65. Santa Fe (NM): SAR.

WARE, J.A. 2014. A Pueblo social history: kinship, sodality, and community in the northern Southwest. Santa Fe (NM): SAR.

Watson, A.S., A. Holeman, S. Fladd, K. Bishop, M. Conger \& S. Morrow. 2014. Damage assessment and data recovery at 29SJ 2384, Roberts' Great House July-August 2013. Report prepared for the National Park Service, Chaco Culture National Historical Park.

Watson, A.S., S. Plog, B.J. Culleton, P.A. Gilman, S.A. LeBlanc, P.M. Whiteley, S. Claramunt \& D.J. Kennett. 2015. Early procurement of scarlet macaws and the emergence of social complexity in Chaco 
Canyon, NM. Proceedings of the National Academy of Sciences of the USA 112: 8238-43. https://doi.org/10.1073/pnas.1509825112

WiLls, W.H. 2017. Water management and the political economy of Chaco Canyon during the Bonito Phase (ca. AD 850-1200). Kiva 83: 369-413.

https://doi.org/10.1080/00231940. 2017.1343109

WilLs, W.H. \& W.B. Dorshow. 2012. Agriculture and community in Chaco Canyon: revisiting
Pueblo Alto. Journal of Anthropological

Archaeology 31: 138-55.

https://doi.org/10.1016/j.jaa.2011.

11.002

Wills, W.H., D.E. Love, S.J. Smith, K.R. Adams, M.R. Palacios-Fest, W.B. Dorshow, B.G.

Murphy, H.V. Mattson \& P.L. Crown. 2016.

Water management at Pueblo Bonito: evidence

from the National Geographic Society trenches.

American Antiquity 81: 449-70.

https://doi.org/10.1017/S0002731600003942

Received: 29 September 2017; Revised: 14 February 2018; Accepted: 27 February 2018 